\title{
Correlation analysis of long-term aged soy sauce taste components and sensory tests
}

\author{
Young In $\mathrm{Jo}^{1}$, Nan-Hee Lee ${ }^{2}$, Ung-Kyu Choi ${ }^{1 *}$ \\ ${ }^{1}$ Department of Food Science \& Technology, Korea National University of Transportation, Jeungpyeong 27909, Korea \\ ${ }^{2}$ Department of Medi-Food HMR Industry, Daegu Hanny University, Gyeongsan 38578, Korea
}

\section{장기숙성 간장 맛성분과 관능검사의 상관 분석}

\author{
조영인 ${ }^{1} \cdot$ 이난희 $^{2} \cdot$ 최웅규 ${ }^{1 *}$ \\ ${ }^{1}$ 한국교통대학교 식품공학과, ${ }^{2}$ 대구한의대학교 메디푸드 HMR산업학과
}

\begin{abstract}
The aim of this study was to predict the taste of long-term aged soy sauce and to identify the ingredients that affect sensory characteristics. Based on the correlation analyses of sensory test scores and contents of taste components in soy sauce after long-term aging, highly significance correlations were detected between sensory test scores and, in decreasign order, $\mathrm{NaCl}$, arginine, glutamic acid, leucine, acetic acid, isoleucine, alanine, aspartic acid and tyrosine contents. Despite significant relationships between the sensory evaluation score and contents of taste components, it was not possible to predict taste and quality based on a single component. A multiple regression model based on 22 taste components explained $94 \%$ of the variance in the taste of long-term aged soy sauce. In a stepwise multiple regression analysis performed by sequentially inputting four highly significant variables $\mathrm{NaCl}$, glutamic acid, methionine and oxalic acid), $69.4 \%$ of the variance in taste could be explained.
\end{abstract}

Keywords : long-term aged soy sauce, multiple regression model, taste

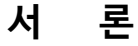

국내에서 소비되는 간장은 크게 한식간장, 양조간장, 산분 해간장 및 혼합간장 등으로 분류되며, 이 중 한식간장은 각종 무침과 국에 짠맛과 더불어 감칠맛을 부여하기 위해 주로 이 용되어 왔다(Choi 등, 2013). 한식간장은 지역에 따라 제조방 법에 다소 차이가 있으나, 공통적으로 고농도의 식염수에 재 래메주를 주원료로 하여 고추, 대추 및 숯 등을 넣어 장기간 숙성시킨 다음 된장을 분리한 여액을 가공한 것으로 조선간 장 또는 국간장으로도 불린다(Kim 등, 2011).

간장은 매년 담가 그 해에 소비하는 것이 일반적이나, 최근
1년 이상 장기 숙성시킨 간장이 상품화되고 있어 이에 대한 연구의 필요성이 높은 상황이다. 2 년 이상 장기간 숙성된 발 효식품에 관한 연구로 장기숙성 한식간장 30 여 종을 전국에 서 수집하여 숙성기간에 따른 미생물과 무기질 함량(Choi 등, 2019), 유리당, 유기산, 유리아미노산의 함량 비교 연구(Jang 등, 2019) 등이 보고된 바 있다. 또한, 1년에서 12년 동안 숙성 된 시판 멸치액젓의 이화학적 성분 및 관능적 특성이 보고된 바 있으며(Nam 등, 2012), 2년 이상 장기 숙성된 중국식 간장 은 단기 숙성된 간장에 비해 풍미와 품질 면에서 우수하며, 미생물 분포에서 다른 패턴을 보인다는 연구가 보고된 바 있 다(Yang 등, 2017). 하지만 장기숙성 간장의 상품화가 활발히

*Corresponding author. E-mail : ukchoi@ut.ac.kr, Phone : +82-43-820-5242, Fax : +82-43-820-5240

Received 20 July 2021; Revised 21 October 2021; Accepted 01 November 2021.

Copyright (c) The Korean Society of Food Preservation.

This is an Open Access article distributed under the terms of the Creative Commons Attribution Non-Commercial License (http://creativecommons.org/licenses/by-nc/4.0) which permits unrestricted non-commercial use, distribution, and reproduction in any medium, provided the original work is properly cited. 
이루어지고 있는 시장의 변화에 비해 이에 대한 체계적인 연 구는 상당히 부진하게 이루어지고 있는 실정이다.

간장의 맛은 유리당, 유기산, 유리아미노산 등 맛을 내는 다양한 성분들의 조합에 의해 형성되는 감미, 고미, 신미, 염 미, 지미에 의해 형성되고, 이들 맛성분의 함량 변화에 따라 간장의 맛이 좌우된다( $\mathrm{Kim}$ 등, 1985). 간장의 관능적 품질 향상을 목적으로 약용식물 추출물 $(\mathrm{Oh}$ 등, 2002) 또는 산수 유, 양파(Won 등, 2012) 등과 같은 천연물을 첨가한 다양한 간장개발이 시도되고 있으며, 발아시킨 콩(Choi 등, 2010; Choi 등, 2011)과 보리등겨 등의 원료를 이용한 간장 개발도 활발히 진행되고 있다(Choi 등, 2005; Lee 등, 2006).

본 연구에서는 장기숙성된 간장을 1년 이하-7년 이상의 6 그룹으로 세분하여 맛성분을 분석하고 관능검사 점수와의 상 관관계를 중회귀 분석을 이용하여 통계적으로 분석하여 장기 숙성 간장의 맛에 영향을 미치는 성분을 밝힘으로써 장기숙 성 간장의 품질표준화를 위한 기초자료로 이용하고자 한다.

\section{재료 및 방법}

\section{간장 시료}

간장 시료는 전국 각지에서 수집된 7종의 1년 미만 숙성 간장과 23종의 장기숙성 간장을 사용하였다(Jang 등, 2019). 사용된 간장의 숙성기간은 1 년 미만 숙성간장이 7종, 1 년 이 상 2년 미만 숙성간장이 3종, 2년 이상 3년 미만 숙성간장이 7종, 3년 이상 5년 미만 숙성간장이 4종, 5년 이상 7년 미만 숙성간장이 4종 및 7년 이상 숙성간장이 5종이었다. 지역별 로는 서울과 경기지역이 1 종, 강원지역이 6종, 경상지역이 9 종, 충청지역이 8종, 전라지역이 6종이었다.

\section{유리당 함량 측정}

간장 시료 $2 \mathrm{~g}$ 에 $80 \%$ 에탄올 용액 $80 \mathrm{~mL}$ 를 가하고, 이형 플라스크에 넣어 $80^{\circ} \mathrm{C}$ heating mantle에서 1시간 동안 추출 하였다. 이 추출액을 자연 냉각시킨 후, $8,000 \times g$ 에서 30 분간 원심분리(Centrifuge Cooled, Combi 514R, Hanil Corp, Gwangju, Korea)하였다. 잔사(residum)에 $80 \%$ 에탄올 용액 $20 \mathrm{~mL}$ 를 가하여 위에 언급한 바와 같이 2 회 반복 추출한 후 상층액을 모두 모아 evaporator(Rotary evaporator, N-1000, Eyela, Tokyo, Japan)로 $40^{\circ} \mathrm{C}$ 에서 감압 농축하였다. 3 차 증 류수를 이용해 $10 \mathrm{~mL}$ 로 정확하게 맞춘 다음, $0.22 \mu \mathrm{m}$ membrane filter(Millipore, Bedford, MA, USA) 및 C18 Seppak cartridge(Waters Associates, Milford, MA, USA)를 차례로 통과시킨 후 HPLC(Agilent 1260 Series, Agilent Technologies, CA, USA)로 분석하였다. 칼럼은 sugar-pak (단당류)과 dextro-pak(소당류)을 사용하였고, 당 검출은 RI detector를 사용하였으며, 이동상(acetonitril:water $=65: 35)$ 의 유속은 단당류 검출 시에는 $0.5 \mathrm{~mL} / \mathrm{min}$, 소당류의 경우는 $1.0 \mathrm{~mL} / \mathrm{min}$ 로 하였다.

\section{유기산 함량 측정}

간장 시료 $200 \mathrm{~g}$ 을 $800 \mathrm{~mL}$ 의 ethanol로 $85^{\circ} \mathrm{C}$ 에서 환류 추 출한 후 여과액을 감압 건조시켰다. 건조된 시료에 3 차 증류 수를 첨가하여 $100 \mathrm{~mL}$ 로 정용한 다음 시료 $1 \mathrm{~mL}$ 를 test tube 형 수기 $(5 \mathrm{~mL})$ 에 넣고, 다시 감압 건조시켰다. 여기에 $14 \%$ $\mathrm{BF}_{3} 2 \mathrm{~mL}$ 를 넣고 밀봉하여 $80^{\circ} \mathrm{C}$ 에서 30 분 동안 반응시킨 후 냉각하였다. 냉각된 시료에 $\left(\mathrm{NH}_{4}\right)_{2} \mathrm{SO}_{4}$ 포화용액 $4 \mathrm{~mL}$ 를 첨가한 후 $\mathrm{CHCl}_{3} 2 \mathrm{~mL}$ 를 첨가하였다. 아래층의 메틸화된 유 기산이 녹아 나온 $\mathrm{CHCl}_{3}$ 층을 주사기로 채취한 다음 pasteur pipette에 비등석으로 입구를 막고, $\mathrm{Na}_{2} \mathrm{SO}_{3}$ 로 $2 / 3$ 정도 채운 다음, 이 피펫에 채취한 액을 흘려보내 수분을 제거하고, 통 과한 액을 받아서 GC(DS6200, Donam systems Inc., Seoul, Korea)로 분석하였다. 칼럼은 DB-FFAP $0.53 \mathrm{~mm} \times 30 \mathrm{~m}$ (Agilent Technologies, MI, USA), 칼럼 온도는 $100^{\circ} \mathrm{C}$ 에서 5 분간 유지한 후 $4^{\circ} \mathrm{C} / \mathrm{min}$ 의 속도로 $220^{\circ} \mathrm{C}$ 까지 상승시키고, $220^{\circ} \mathrm{C}$ 에서 5 분 동안 유지시켰다. 주입기 온도 $230^{\circ} \mathrm{C}$, 검출기 (FID) 온도 $250^{\circ} \mathrm{C}$, 운반 기체는 $\mathrm{N}_{2}(2 \mathrm{~mL} / \mathrm{min})$ 를 유속 35.8 $\mathrm{mL} / \mathrm{min}$ 으로 하여 분석하였다.

\section{유리아미노산 함량 측정}

간장 시료 $200 \mathrm{~g}$ 을 $800 \mathrm{~mL}$ 의 ethanol에 넣고 $85^{\circ} \mathrm{C}$ 에서 2 시간 동안 환류추출한 후 여과액을 감압 건조하여 얻은 건조 시료에 3차 증류수를 첨가하여 $100 \mathrm{~mL}$ 로 정용한 다음, Amberlite IR-118H와 Amberlite IRA-400(Sigma-Aldrich, $\mathrm{MO}, \mathrm{USA}$ )이 각각 충전된 칼럼에 연속 통과시켰다. 양이온 교환수지에 흡착된 아미노산은 $5 \% \mathrm{NH}_{4} \mathrm{OH}$ 용액 $300 \mathrm{~mL}$ 로 용출시켜 감압농축한 후, $0.2 \mathrm{~N}$ sodium citrate( $\mathrm{pH}$ 2.2)로 5 배 희석한 다음, membrane filter $(0.2 \mu \mathrm{m})$ 로 여과한 액 $20 \mu \mathrm{L}$ 를 아미노산 자동 분석기(Bio chrom 30 amino acid analyzer, Amersham bioscience, England, UK)로 분석하였다. Sodium citrate buffer의 유속은 $35 \mathrm{~mL} / \mathrm{h}$, ninhydrin의 유속은 25 $\mathrm{mL} / \mathrm{h}$, 온도 기울기는 $46,50,95$ 및 $46^{\circ} \mathrm{C}$, 분석파장은 440 $\mathrm{nm}$ 와 $570 \mathrm{~nm}$, 칼럼은 cation exchange resin을 사용하여 분 석하였다.

\section{식염 $(\mathrm{NaCl})$ 함량 측정}

식염 함량은 Mohr법(Oh 등, 2002)을 사용하여 분석하였 다. 간장 $1 \mathrm{~mL}$ 를 증류수로 100 배 희석하여 실온에서 진탕 후 $10 \mathrm{~mL}$ 를 취한 뒤 $10 \% \mathrm{~K}_{2} \mathrm{CrO}_{4} 1 \mathrm{~mL}$ 를 첨가한 다음 $\mathrm{AgNO}_{3}$ 를 이용하여 적정하였다. 


\section{관능검사}

장기숙성 간장의 관능적 품질 평가를 조사하기 위해 관능 검사 패널 34 명을 선정하여 종합적 기호도에 대한 관능평가 를 9점 척도법으로 실시하였다. 그 기준은 굉장히 싫다(1점), 싫다(3점), 보통이다(5점), 좋다(7점), 굉장히 좋다(9점)로 평 가하고, 그 합으로 나타내었다. 이 때 각 시료에는 검사의 오 류를 방지하기 위해 난수표에서 추출한 세 자리 숫자를 임의 로 표시하였으며, 시료는 무작위 순서로 배치하였다(IRB 승 인번호: KNUT IRB 2019-3).

\section{중회귀분석}

중회귀분석은 Aishima와 Nobuhara의 방법(1976)에 따라 분석하였다. 장기숙성 간장 시료 $\mathrm{n}$ 개의 맛을 각각 관능검사 로 채점하여 각 시료에 대응하는 1 군의 관능검사 점수를 얻 었다. 이때, 각각의 장기숙성 간장에 대한 관능검사 점수는 $\mathrm{Y}=\left(\mathrm{y}_{1}, \mathrm{y}_{2}, \cdots, \mathrm{y}_{\mathrm{i}}, \cdots, \mathrm{y}_{\mathrm{n}}\right) 1<\mathrm{i}<\mathrm{n}$ 으로 표시할 수 있다. 또, 장기숙성 간장의 맛을 가능한 원래의 조직 성분을 지닌 상태 에서 추출, 분석하여 22 개의 맛 성분을 각 시료로부터 확보하 였다.

만약, 장기숙성 간장의 맛과 향에 영향을 미치는 성분이 $\mathrm{m}$ 개라면 각 성분은 $\left(\mathrm{x}_{\mathrm{i} 1}, \mathrm{x}_{\mathrm{i} 2}, \cdots, \mathrm{x}_{\mathrm{ij}}, \cdots, \mathrm{x}_{\mathrm{im}}\right), 1<\mathrm{j}<\mathrm{m}$ 으로 표시되고, 결과적으로 모든 시료의 맛성분 분석 결과치는 $\mathrm{n} \times \mathrm{m}$ 개의 행렬로 나타내어진다. 이 두 가지 행렬의 관계를 중 회귀분석으로 해석하였다. 중회귀분석 식은 아래의 식 (1)과 같이 나타낼 수 있다.

$$
\mathrm{Y}=\beta_{\mathrm{o}}+\beta_{1} \mathrm{X}_{1}+\beta_{2} \mathrm{X}_{2}+\cdots+\beta_{\mathrm{j}} \mathrm{X}_{\mathrm{j}}+\cdots+\beta_{\mathrm{m}} \mathrm{X}_{\mathrm{m}}+\varepsilon
$$

여기서 $\mathrm{Y}$ 는 종속변수로써 관능검사 점수를 나타내고, $\beta_{0}$ 는 정수, $\beta_{\mathrm{j}}$ 는 편회귀계수, $\varepsilon$ 는 표준오차, $\mathrm{X}_{\mathrm{i}}$ 는 각 맛성분의 집합 으로써 독립변수를 나타낸다. $\beta_{0}$ 와 $\beta_{\mathrm{j}}$ 는 최소선형제곱법에 의 해 계산되었고, 이 등식은 $\mathrm{i}$ 가 $\mathrm{j}$ 보다 커야 성립된다. 본 실험 에서 i가 30 개, $\mathrm{j}$ 가 22 개였다. 중회귀 분석에서 관능평가 점수 와 산출된 중회귀식에 의해 추정된 점수와의 상관계수는 중 상관계수(R)이며, 결정계수는 $\mathrm{R}^{2}$, 기여율은 $\mathrm{R}^{2} \times 100$ 으로, 이 수치들은 관능검사 점수의 변동 가운데 산출된 중회귀식에 의해 설명되는 비율을 나타낸다.

\section{결과 및 고찰}

\section{맛성분 함량과 관능검사}

수집된 30 종의 장기숙성 간장을 대상으로 맛성분 함량을 측정한 결과의 평균, 표준편차, 최대값, 최소값은 Table 1에
요약하였다. 맛 성분으로는 유리당, 유기산, 유리아미노산 및 $\mathrm{NaCl}$ 이 분석되었다. 수집된 간장 30 종의 유리당 함량을 확인 한 결과, 유리당은 maltose, sucrose, fructose 및 glucose를 분 석하였으나, glucose 외의 성분은 검출되지 않았다. 30 종에서 검출된 glucose의 함량은 $14.1 \pm 19.8 \mathrm{mg} \%$ 였으며, 최대값과 최소값은 각각 55.8 과 $0 \mathrm{mg} \%$ 로 나타났다. 재래식으로 제조 된 간장 중의 유리당은 그 종류와 함량에서 다소 차이를 보이 고 있으나 일반적으로 $200-350 \mathrm{mg} \%$ 정도 함유되어 있으며, 주원료로 검정콩을 이용한 간장에서 유리당 함량이 상대적으 로 높은 것으로 보고되어 있다(Kwon 등, 2003). Lee 등 (2002)의 연구에 따르면 보리등겨를 주원료로 간장을 제조하 여 120 일 동안 발효시키면서 유리당 함량 변화를 확인한 결 과, 발효 60 일 이후부터 급격한 감소 패턴을 보인다고 보고한 바 있다. 본 연구에 사용된 간장은 숙성기간이 최대 7년 이상 인 것으로 발효가 진행됨에 따라 미생물에 의해 소비되어 함 량이 상대적으로 낮게 나온 것으로 판단된다.

숙성기간에 차이를 두어 수집된 간장의 유기산 함량을 확 인한 결과, 유기산은 oxalic, citric, tartaric 및 acetic acid 등 총 4종이 검출되었다. 유기산의 함량은 acetic acid가 가장 많 았으며, citric acid와 oxalic acid의 순이었다. Acetic acid의 함량은 $298.1 \pm 201.8 \mathrm{mg} \%$ 였으며, 최대값과 최소값은 각각 637.5 와 $0 \mathrm{mg} \%$ 로 나타났다. 증자조건을 달리한 검은콩 간장 의 총유기산 함량은 $22.78-76.96 \mathrm{mg} \%$ 의 범위이며, 증자조건 에 따른 유기산 함량의 변화는 상당히 큰 것으로 보고되어 있다(Kwon 등, 2003). Lee 등(2002)에 따르면 훈연한 보리등 겨로 발효시킨 간장의 유기산 함량을 확인한 결과, 발효가 지 속됨에 따라 휘발성 유기산은 감소하는 반면, 비휘발성 유기 산의 함량은 증가한다고 하여 장기숙성 간장의 유기산 함량 이 높을 가능성을 예측한 바 있다. 2년 이상 장기숙성된 간장 의 유기산 함량에 관한 자료는 현재까지 보고된 바 없으며, 본 연구결과 간장을 장기간 숙성할 경우 유기산 함량은 증가 하는 패턴을 보이는 것으로 판단된다.

장기 숙성된 간장의 유리아미노산 함량을 확인한 결과, 아 미노산은 총 16 종이 분석되었다. 유리아미노산은 glutamic acid의 함량이 가장 높았으며, alanine, leucine, aspartic acid 및 lysine의 순으로 높은 것으로 확인되었다. 간장의 발효초 기에는 유리아미노산의 함량이 발효시간에 비례하여 증가하 지만(Lee 등, 2002), 1 년 이상 장기 숙성한 간장의 유리아미 노산 변화에 대한 보고는 현재까지 확인된 바 없다. Ko 등 (2003)에 따르면 검은콩을 이용하여 제조한 간장의 아미노산 함량이 133-451.5 mg\%로 확인되었다고 보고하여 본 연구결 과와는 약간의 차이를 보였는데, 이는 간장 숙성기간의 차이 와 발효환경, 주원료 및 발효 미생물 등 다양한 원인의 차이 에 기인하는 것으로 판단된다. 
Table 1. Mean, standard deviation, maximum and minimum values of taste compounds (free amino acids, free sugars, organic acids and $\mathrm{NaCl}$ ) of long-term aged Korean soy sauce

\begin{tabular}{|c|c|c|c|c|c|}
\hline \multicolumn{2}{|c|}{ Taste compounds } & Mean & SD & Max. & Min. \\
\hline \multirow{16}{*}{$\begin{array}{l}\text { Amino } \\
\text { acid } \\
(\mathrm{mg} \%)\end{array}$} & Thr & 107.9 & 37.1 & 177.9 & 45.2 \\
\hline & Ser & 135.4 & 54.8 & 237.3 & 50.8 \\
\hline & Gly & 128.1 & 37.9 & 207.1 & 42.4 \\
\hline & Ala & 334.1 & 140.0 & 653.6 & 151.2 \\
\hline & Lys & 252.7 & 61.0 & 463.4 & 167.1 \\
\hline & Asp & 285.1 & 124.8 & 616.5 & 0.0 \\
\hline & Glu & 721.8 & 190.4 & $1,225.9$ & 500.2 \\
\hline & Met & 65.6 & 85.8 & 505.0 & 0.0 \\
\hline & Ile & 197.5 & 48.5 & 307.4 & 131.0 \\
\hline & Leu & 319.3 & 80.2 & 534.6 & 147.4 \\
\hline & Pro & 100.8 & 65.2 & 246.3 & 0.0 \\
\hline & Val & 40.9 & 23.2 & 95.0 & 0.0 \\
\hline & Tyr & 171.9 & 45.5 & 265.4 & 95.0 \\
\hline & Phe & 123.9 & 41.3 & 248.1 & 55.7 \\
\hline & His & 69.3 & 21.9 & 137.4 & 30.6 \\
\hline & Arg & 227.7 & 61.9 & 387.3 & 150.3 \\
\hline \multirow{4}{*}{$\begin{array}{c}\text { Organic } \\
\text { acid } \\
(\mathrm{mg} \%)\end{array}$} & Oxalic & 7.3 & 7.7 & 34.5 & 3.1 \\
\hline & Citric & 80.1 & 112.5 & 567.3 & 0.0 \\
\hline & Tartaric & 0.7 & 1.3 & 3.8 & 0.0 \\
\hline & Acetic & 298.1 & 201.8 & 637.5 & 0.0 \\
\hline \multirow{4}{*}{$\begin{array}{c}\text { Sugar } \\
(\mathrm{mg} \%)\end{array}$} & Glucose & 14.1 & 19.8 & 55.8 & 0.0 \\
\hline & Fructose & ND & - & - & - \\
\hline & Maltose & ND & - & - & - \\
\hline & Sucrose & ND & - & - & - \\
\hline \multicolumn{2}{|c|}{$\mathrm{NaCl}(\%)$} & 24.7 & 3.4 & 29.8 & 15.9 \\
\hline \multicolumn{2}{|c|}{ SEV } & 173.2 & 19.1 & 202.0 & 132.0 \\
\hline
\end{tabular}

Thr, threonine; Ser, serine; Gly, glycine; Ala, alanine; Lys, lysine; Asp, apartic acid; Glu, glutamic acid; Met, methionine; Ile, isoleucine; Leu, leucine; Pro, proline; Val, valine; Tyr, tyrosine; Phe, phenylalanine; His, histidine; Arg, arginine; Oxalic, oxalic acid; Citric, citric acid; Tartaric, tartaric acid; Acetic, acetic acid; SEV, sensory evaluation value.

장기 숙성된 간장 30 종의 식염함량은 $24.7 \pm 3.4 \%$ 로 나타났 으며, 최대값과 최소값은 각각 $29.8 \%$ 와 $15.9 \%$ 로 확인되었 다. 장기숙성 간장 30 종에 대해 34 명의 패널을 대상으로 실 시한 관능검사 결과, 점수는 $173.2 \pm 19.1$ 로 나타났으며, 최대 값과 최소값은 각각 202 와 132 로 확인되었다.

\section{각 성분 함량과 관능검사 점수의 단순상관}

장기숙성 간장의 관능검사 점수와 맛성분 함량 사이의 상 관계수를 산출한 결과는 Table 2에 나타내었다. 이 결과에서 양 $(+)$ 의 값은 간장의 맛에 긍정적 영향을 미친다는 것을 의미 하고 음(-)의 값은 부정적 영향을 미친다는 것을 의미한다.

$\mathrm{NaCl}$, arginine, glutamic acid, leucine, acetic acid, isoleucine, alanine, aspartic acid 및 tyrosine의 순서대로 각 성분과 관능 평가 점수 사이의 상관계수가 유의성이 높은 것으로 나타났 다. $\mathrm{NaCl}$ 함량은 간장 맛에 상당히 긍정적인 영향을 미치는

Table 2. Correlation coefficients (r) between sensory scores and contents of taste compounds

\begin{tabular}{|c|c|c|c|}
\hline \multicolumn{2}{|c|}{ Compounds } & $\mathrm{r}$ & Order \\
\hline \multirow{11}{*}{$\begin{array}{l}\text { Amino } \\
\text { acid }\end{array}$} & Thr & -0.342 & 11 \\
\hline & Ser & -0.312 & 14 \\
\hline & Gly & 0.298 & 15 \\
\hline & Ala & $0.492^{* *}$ & 7 \\
\hline & Lys & 0.322 & 13 \\
\hline & Asp & $0.478^{* *}$ & 8 \\
\hline & Glu & $0.546^{* *}$ & 3 \\
\hline & Met & 0.336 & 12 \\
\hline & Ile & $0.529^{* *}$ & 6 \\
\hline & Leu & $0.532^{* *}$ & 4 \\
\hline & Pro & 0.118 & 17 \\
\hline \multirow{5}{*}{$\begin{array}{l}\text { Amino } \\
\text { acid }\end{array}$} & Val & -0.016 & 21 \\
\hline & Tyr & $0.422^{*}$ & 9 \\
\hline & Phe & 0.065 & 19 \\
\hline & His & 0.053 & 20 \\
\hline & Arg & $0.547^{* *}$ & 2 \\
\hline \multirow{4}{*}{$\begin{array}{l}\text { Organic } \\
\text { acid }\end{array}$} & Oxalic & -0.101 & 18 \\
\hline & Citric & -0.263 & 16 \\
\hline & Tartaric & -0.006 & 22 \\
\hline & Acetic & $0.529^{* *}$ & 5 \\
\hline Sugar & Glucose & -0.400 & 10 \\
\hline \multicolumn{2}{|c|}{$\mathrm{NaCl}$} & $0.587^{* *}$ & 1 \\
\hline
\end{tabular}

Thr, threonine; Ser, serine; Gly, glycine; Ala, alanine; Lys, lysine; Asp, apartic acid; Glu, glutamic acid; Met, methionine; Ile, isoleucine; Leu, leucine; Pro, proline; Val, valine; Tyr, tyrosine; Phe, phenylalanine; His, histidine; Arg, arginine; Oxalic, oxalic acid; Citric, citric acid; Tartaric, tartaric acid; Acetic, acetic acid.

p $<0.05,{ }^{* *} \mathrm{p}<0.01$. 
것으로 나타났으며, glucose는 간장의 맛에 부정적인 영향을 미치는 것으로 확인되었다. 유기산의 경우, acetic acid는 장 기숙성 간장의 맛에 긍정적 기여를 하지만 citric, oxalic 및 tartaric acid는 기여도가 상당히 낮은 것으로 확인되었다. 유 리아미노산의 경우, 유의적으로 부정적 기여를 하는 아미노 산은 없었으며, glutamic acid와 arginine 등 7가지 성분이 유 의적으로 긍정적 기여를 하는 것으로 확인되었다.

장기숙성 간장의 맛에 긍정적 영향을 미치는 성분인 glutamic $\operatorname{acid}\left(\mathrm{r}=0.546^{* *}\right)$ 와 부정적 영향을 미치는 threonine $(\mathrm{r}=-0.342)$ 의 함량과 관능검사 점수와의 관계를 Fig. 1 에 나 타내었다. 관능검사 점수와 각 성분의 함량 사이에는 유의미 한 관계가 있음에도 불구하고, 단지 하나의 성분함량을 기준 으로 장기숙성 간장의 맛과 품질을 예측하는 것은 불가능하 다는 것을 확인할 수 있었다. 이는 간장의 맛을 예측하기 위 해서는 다양한 성분의 조합을 통해 설명되어야 한다는 것을 의미한다.

\section{중회귀 분석}

각각의 시료에서 22 개씩의 맛성분을 독립변수로 하고, 관 능검사 점수를 종속변수로 하여 중회귀 분석을 실시한 결과 를 Fig. 2에 나타내었다. 각 편회귀 계수의 부호와 상관계수 의 부호가 반드시 일치하지 않는 것은 독립변수, 즉 맛성분 함량의 증감에 상관관계가 존재하기 때문이다. 중 회귀식에
중상관계수, F-value와 함께 통계적 유의성을 표시한 결과, 관능평가 점수와 맛성분 패턴 사이에 단순상관이 존재함을 알 수 있었다. 또, 각 편회귀 계수를 t-test로 조사한 결과 다 수의 독립변수를 포함하고 있음에도 불구하고, 비교적 다수 의 유의점을 표시한 성분이 존재하였다. 이 결과는 장기숙성 간장의 맛을 중회귀분석식과 맛성분의 함량으로부터 추정하 는 것이 가능하다는 것을 의미한다. 이 결과로부터 산출된 중 회귀식을 근거로 추정한 점수와 관능평가 점수 사이의 관계 는 Fig. 3에 나타내었다. Fig. 3에서 보여지듯이 중회귀식을 근거로 추정한 관능검사 점수와 실제 관능검사 점수 사이에 높은 상관관계가 존재하여 맛성분의 함량과 중회귀 분석식에 의한 각 시료의 관능검사 점수를 추정하는 것이 유의미하다 는 것을 확인할 수 있었다.

\section{단계적 중회귀 분석}

중회귀식을 근거로 추정한 관능검사 점수와 실제 관능평 가 점수 사이에 높은 상관관계가 존재하여 맛성분 함량과 중 회귀 분석식에 의한 각 시료의 관능평가 점수를 추정하는 것 이 가능하였으나 변수가 22개로 비교적 많았으며, 이를 줄일 경우 효율성이 높을 것으로 판단되어 유의성이 높은 최소한 의 변수를 이용한 회귀식을 산출하고자 하였다. 즉, 단계적 중회귀분석에 의해 회귀모형을 나타내었을 때, 관능검사 결 과값을 설명하기 위한 독립변수로 $\mathrm{NaCl}$, glutamic acid,
(A)

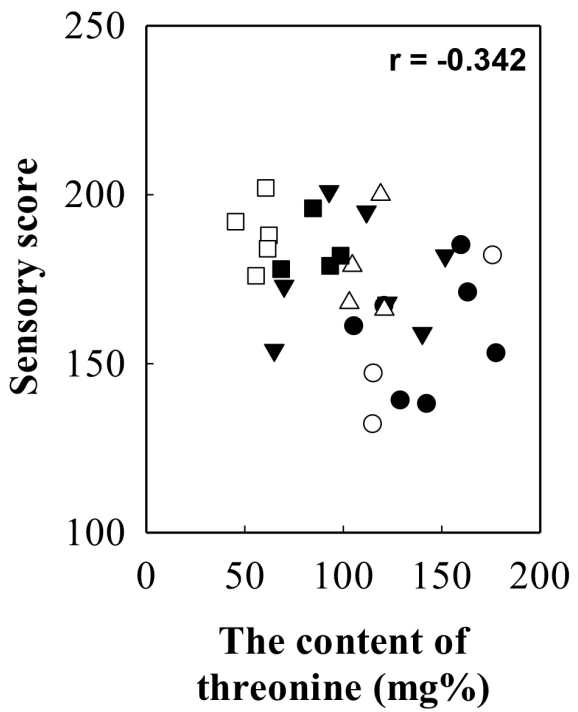

(B)

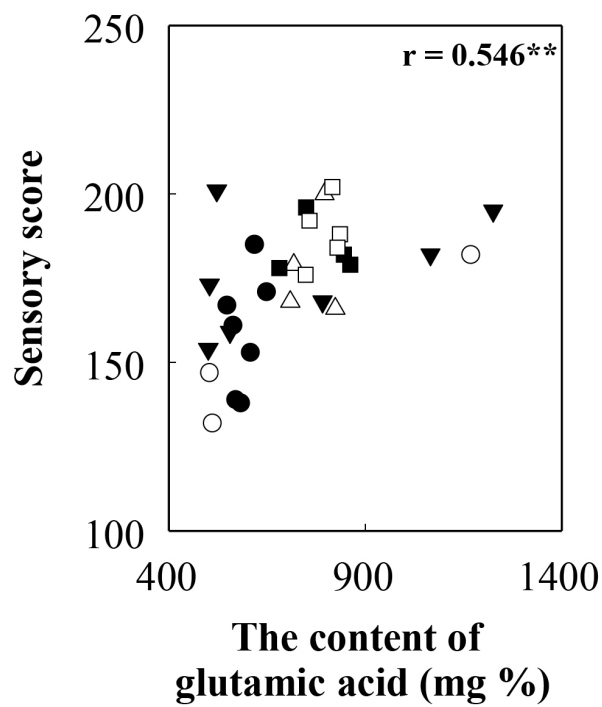

Fig. 1. Simple correlation between sensory scores and content of principal components. (A) threonine, (B) glutamic acid.

- -1 year or less; $\bigcirc-\bigcirc, 1$ year or more but less than 2 years; $\nabla-\nabla, 2$ years or more but less than 3 years; $\triangle-\triangle, 3$ years or more but less than 5 years; $\square-\square, 5$ years or more but less than 7 years; $\square-\square, 7$ years or more. 
$\mathrm{Y}=50.783+0.692(\mathrm{Thr})-0.036(\mathrm{Ser})-0.609$ (Gly) +0.241 (Ala)
(0.547:-) (1.295:-)
$(-0.292:-)$
$(-1.663:-)$
(1.010:-)

-0.438 (Lys) +0.185 (Asp) -0.049 (Glu) +0.089 (Met) +0.780 (Ile)

$\left(-2.543:^{*}\right) \quad(0.907:-) \quad(-0.589:-) \quad\left(2.841:^{*}\right) \quad(2.149:-)$

+0.056 (leu) -0.035 (Pro) $-0.449($ Val $)-1.003$ (Tyr) $+0.473($ Phe $)$

$(0.470:-) \quad(-0.140:-) \quad(-0.965:-) \quad(-2.146:-) \quad(1.371:-)$

- 0.009(His) - 0.050(Arg) - 2.339(Oxalic) - 0.095(Citric)

(-0.028:-) (-0.190:-) (-1.117:-) (-2.628:")

- 7.969(Tartaric) +0.024 (Acetic) +0.526 (Glucose)

(-1.653:-) (0.317:-) (1.124:-)

$+5.200(\mathrm{NaCl})$

(1.535:-)

$\mathrm{R}=0.970, \mathrm{R}^{2}=0.940, \mathrm{~F}=5.019^{*}, \mathrm{SE}=9.476$

Fig. 2. Multiple regression models computed from the taste compounds and sensory evaluation score.

Thr, threonine; Ser, serine; Gly, glycine; Ala, alanine; Lys, lysine; Asp, apartic acid; Glu, glutamic acid; Met, methionine; Ile, isoleucine; Leu, leucine; Pro, proline; Val, valine; Tyr, tyrosine; Phe, phenylalanine; His, histidine; Arg, arginine; Oxalic, oxalic acid; Citric, citric acid; Tartaric, tartaric acid; Acetic, acetic acid. * $<<0.05$.

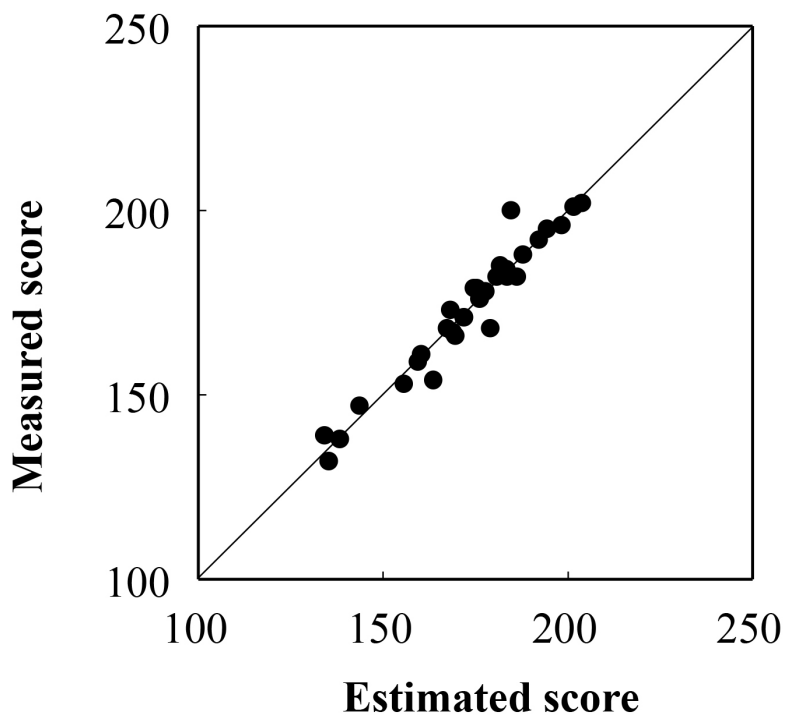

Fig. 3. Simple correlation between measured sensory scores and estimated sensory scores derived from multiple regression models with 22 taste compounds.

methionine, oxalic acid 등 네 가지의 변수를 차례로 모형에 포함시켜 중회귀 분석을 실시하였다. $\mathrm{NaCl}$ 만 포함되었을 때 의 결정계수 $\left(\mathrm{R}^{2}\right)$ 는 0.345 로, 관능검사 결과값의 $34.5 \%$ 를 설
명함을 의미한다. 여기에 glutamic acid가 추가되었을 때의 결정계수는 0.534 , methionine이 추가되었을 때의 결정계수 는 0.645 , oxalic acid가 추가되었을 때의 결정계수는 0.694로 확인되었다. 이 네 가지 독립변수가 모두 포함된 회귀모형의 $\mathrm{F}$ 값은 $14.179(\mathrm{p}<0.001)$ 로 나타나, 이 회귀모형이 통계적으로 유의미함을 알 수 있었다. 이러한 과정을 거쳐 얻어진 관능검 사에 대한 회귀식은 Fig. 4 에 나타낸 바와 같다. 선택된 5 개 의 변수 중 $\mathrm{NaCl}$, glutamic acid 및 methionine은 $5 \%$ 유의수 준에서 유의성이 있는 것으로 나타났다. 유의성이 높은 네 가 지의 변수를 차례로 투입하여 얻은 중회귀식의 상관계수는 0.833 이었으며, 결정계수는 0.694 로 확인되었다. 이는 $\mathrm{NaCl}$, glutamic acid, methionine, oxalic acid 등 네 가지의 변수만 으로 장기숙성 간장 맛의 $69.4 \%$ 를 설명할 수 있다는 것을 의 미한다.

네 가지 변수로부터 얻어진 중회귀분석식을 근거로 추정한 점수와 실제로 얻어진 관능검사 점수와의 관계를 Fig. 5에 나 타내었다. 총 22 개의 변수에서 단지 4 개의 변수만을 이용하여 예측한 모델임에도 불구하고, 중회귀식을 근거로 추정한 관능 검사 점수와 실제 관능검사 점수 사이에 높은 상관관계가 존 재하였다. 이는 맛성분의 함량과 중회귀분석식에 의한 각 시 료의 관능검사 점수를 추정하는 것이 가능하다는 것을 의미한 다. 이는 향후 장기숙성 간장의 관능적 우수성을 확인하고자 하는 연구에서 관능검사를 실시하지 않고 다섯 가지의 성분분 석 결과를 바탕으로 예측이 가능하다는 측면에서 비용과 시간 을 상당히 줄일 수 있다는 측면에서 의미가 있다고 판단된다.

중회귀분석을 이용하여 발효식품의 맛을 예측한 연구로 Choi 등(2004)은 보리등겨로 제조한 간장 맛의 좋고 나뽐을 93\%의 정확도로 추정할 수 있다고 보고한 바 있으며, Choi 등(1999)은 시금장의 맛과 가장 상관이 높은 성분은 inositol 과 fructose였으며, 변수변환을 통하여 16 개의 성분으로 시금 장 맛의 $90 \%$ 를 설명할 수 있다고 보고한 바 있다. 본 연구 결과, 22 개의 성분 분석과 관능검사 결과를 바탕으로 장기숙 성 간장 맛의 $94.0 \%$ 를 설명할 수 있었으며, 단계적 중회귀 분석에서 4 개의 성분으로 $64.5 \%$ 의 예측이 가능하였다.

$$
\begin{aligned}
& \mathrm{Y}=73.707+2.250(\mathrm{NaCl})+0.060(\mathrm{Glu})+0.070(\mathrm{Met})-0.591(\text { Oxalic }) \\
& \left(4.519::^{*}\right) \quad\left(3.414:^{*}\right) \quad\left(4.935:^{*}\right) \quad\left(2.674::^{*}\right) \quad(-2.003:-) \\
& \mathrm{R}=0.833, \mathrm{R}^{2}=0.694, \mathrm{~F}=14.179^{* *}, \mathrm{SE}=11.359
\end{aligned}
$$

Fig. 4. Stepwise multiple regression models computed from the 4 taste compounds ( $\mathrm{NaCl}$, glutamic acid, methionine, oxalic acid) and sensory evaluation score.

Glu, glutamic acid; Met, methionine; Oxalic, oxalic acid. ${ }^{*} \mathrm{p}<0.05,{ }^{* *} \mathrm{p}<0.01$. 


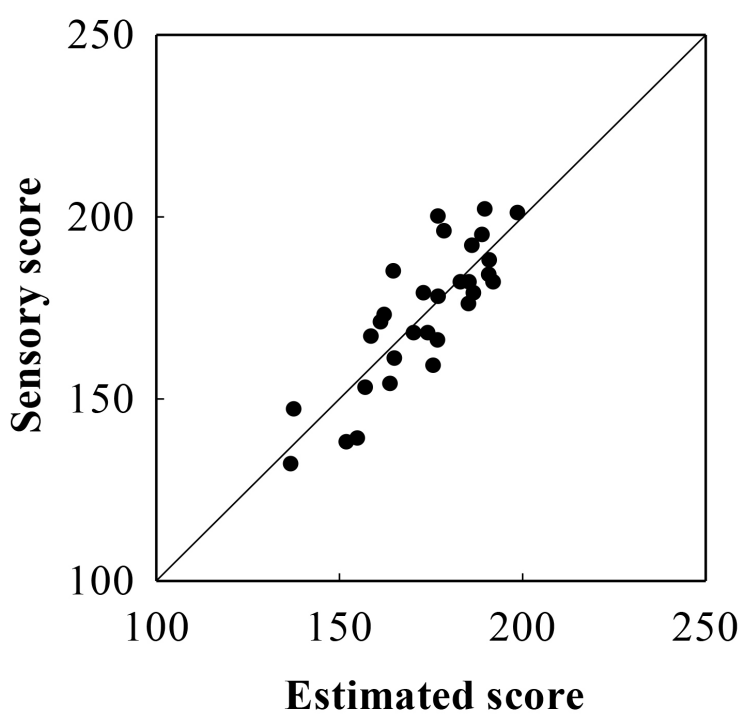

Fig. 5. Simple correlation between sensory scores and estimated sensory scores derived from stepwise multiple regression models with 4 taste compounds ( $\mathrm{NaCl}$, glutamic acid, methionine, oxalic acid).

\section{요 약}

본 연구에서는 장기숙성 간장의 맛성분 분석 결과와 관능 평가 점수 사이의 통계적 분석을 통해 장기숙성 간장의 맛을 예측하고 영향을 미치는 성분을 확인하고자 하였다. 장기숙 성 간장의 관능평가 점수와 맛성분 함량과의 상관계수를 산출 한 결과, $\mathrm{NaCl}$, arginine, glutamic acid, leucine, acetic acid, isoleucine, alanine, aspartic acid 및 tyrosine의 순서대로 관 능평가 점수 사이의 상관계수가 유의성이 높은 것으로 나타 났다. 관능평가 점수와 성분함량 사이에는 유의미한 관계가 있음에도 불구하고, 하나의 성분함량을 기준으로 장기숙성 간장의 맛과 품질을 예측하는 것은 불가능하였다. 각각의 시 료에서 22개씩의 맛성분을 독립변수로 하고, 관능검사 점수 를 종속변수로 하여 중회귀 분석을 실시한 결과, 장기숙성 간 장 맛의 $94 \%$ 를 추정하는 것이 가능하였다. 유의성이 높은 네 가지의 변수 $(\mathrm{NaCl}$, glutamic acid, methionine, oxalic acid)를 차례로 투입하여 단계적 중회귀 분석을 실시한 결과, 장기숙 성 간장 맛의 $69.4 \%$ 를 설명할 수 있었다.

\section{Conflict of interests}

The authors declare no potential conflict of interest.

\section{ORCID}

Young In Jo

https://orcid.org/0000-0002-1747-7126
Ung-Kyu Choi https://orcid.org/0000-0002-4551-8693

\section{References}

Aishima T, Nobuhara A. Evaluation of soy sauce flavor by stepwise multiple regression analysis of gas chromatographic profiles. Agric Bio Chem, 40, 2159-2167 (1976)

Choi WS, Lee NH, Choi UK. Comparison of quality characteristics of long-term matured Korean soy sauce. Korean J Food Nutr, 32, 530-535 (2019)

Choi UK, Park JH. Evaluation of taste in Kanjang made with barley bran using multiple regression analysis. Korean J Food Sci Technol, 36, 75-80 (2004)

Choi UK, Son DH, Ji WD, Choi DH, Kim YJ, Rhee SW, Chung YG. Producing method and statistical evaluation of taste of Sigumjang. Korean J Food Sci Technol, 31, 778-787 (1999)

Jang HS, Lee NH, Choi UK. Taste components and sensory characteristics of long-tern matured Korean soy sauce. Korean J Food Nutr, 32, 349-354 (2019)

Kim DH, Yook HS, Kim KY, Shin MG, Byun MW. Fermentative characteristics of extruded Meju by the molding temperature. J Korean Soc Food Sci Nutr, 30, 250-255 (2011)

Kim JK, Chung YG, Yang SH. Effective components on the taste of ordinary Korean soy sauce. Kor J Appl Microbiol Bioeng, 13, 285-287 (1985)

Ko YR, Kwon SH, Choi J, Shon MY, Park SK. Nitrogen compounds and free amino acids of black bean Kanjang prepared with different cooking conditions of whole black bean. Korean J Food Preserv, 10, $75-79$ (2003)

Kwon SH, Choi J, Ko YR, Shon MY, Park SK. Changes in free sugars, organic acids and fatty acid composition of Kanjang prepared with different cooking conditions of whole black bean. Korean J Food Preserv, 10, 333338 (2003)

Lee EJ, Kwon OJ, Choi UK, Son DH, Kwon OJ, Lee SI, Yang SH, Im MH, Kim DG, Chung YG. Changes in taste components of Kanjang made with barley bran during fermentation. Korean J Food Sci Technol, 34, 85-90 (2002)

Nam KH, Jang MS, Park HY. Component changes in commercial salt-fermented anchovy sauce by long fermentation. J Agricult Life Sci, 46, 99-107 (2012) 
Oh JY, Kim YS, Shin DH. Changes in physicochemical characteristics of low-salted Kochujang with natural preservatives during fermentation. Korean J Food Sci Technol, 34, 835-841 (2002)

Won SB, Oh KH, Jung SU, Song HS. Sensory evaluation hutgae (Hovenia dulcis Thumb) extract for soy sauce development. Korean J Food Nutr, 25, 266-273 (2012)

Yang Y, Deng Y, Jin Y, Liu Y, Xia B, Sun Q. Dynamics of microbial community during the extremely long-term fermentation process of a traditional soy sauce. J Sci Food Agric, 97, 3220-3227 (2017)

Choi UK, Jeong YS, Kwon OJ, Park JD, Kim YC. Comparative study of quality characteristics of Korean soy sauce made with soybeans germinated under dark and light conditions. Int $\mathrm{J}$ Mol Sci, 12, 8105-8118 (2011)

Choi UK, Bajpai VK. Comparative study of quality characteristics of meju, a Korean soybean fermentation starter, made by soybeans germinated under dark and light conditions. Food Chem Toxicol, 48, 356-362 (2010)

Lee NH, Kang SC, Jeong HJ, Kwon OJ, Choi UK. Effective components on the taste of Kanjang made with barley bran using multiple regression analysis. J Korean Soc Appl Biol Chem, 49, 35-42 (2006)

Choi UK. Evaluation of barley bran sauce aroma by multiple regression analysis. Food Sci Biotechnol, 14, 656-660 (2005) 